\title{
Ultilization of Food Additives as Agricultural Fungicides
}

\author{
Tomomasa Misato*, Hachiro Wakamatsu**, Takao Natsume*** \\ and Akio YoshiokA****, Kunihei KIsHI ${ }^{* * * * *}$ \\ 見里朝正*・若松八郎**・夏目孝男***・吉岡昭夫****・岸 国平*****： \\ 食品添加物の農用殺菌剤としての利用
}

We have studied three groups of biodegradable fungicides which may not bring about the possibility of environmental pollution. The first group contains antibiotics, microbial products ${ }^{1}$. After the successful application of blasticidin $\mathrm{S}$ as an antifungal antibiotic ${ }^{2)}$, we are now developing the application of aabomycin as antiviral antibiotic. The second group contains complexes of amino acids and fatty acids, which are essential elements of all organisms ${ }^{3}$. We have found that $N$-lauroyl-L-valine, a complex of lauric acid and valine combined by $N$-acyl linkage, shows an excellent preventive effect against plant fungal diseases. The third group contains food additives, which have been derived from natural sources. We have found that the phosphatides such as soybean lecithin exhibit excellent effects against some plant diseases such as cucumber powdery mildew etc.

As can be readily appreciated from the fact that the food additives are widely used in the food industry, they are considered to posses substantially no mammalian toxicities. The safeties of food additives are exceedingly great, with the consequence that though they may be residually present in crops, the crops can be directly used as food of human or cattle and poultry feed, or after their simple washing. Thus it becomes possible to use the food additives up to immediately before the harvesting period, which has been avoided in the case of the conventional fungicidal compositions. They can be applied with special convenience up to the time of harvesting of fruit-bearing plants, berrybearing plants and vegetables.

\section{The primary screening test}

From the point of view described above, we have screened about 200 kinds of food additives as protective agents against plant diseases. The effectiveness of preventing rice blast disease was examined as the primary screening test. Rice seedlings (variety "Jukkoku") were planted on synthetic resin pots of $6 \mathrm{~cm}$ in diameter, ten seedlings being planted per pot, and were grown in a greenhouse. Food additives were dissolved in $0.5 \mathrm{ml}$ of $80 \%$ ethanol and adjusted to a concentration of $2,000 \mathrm{ppm}$ with tap water.

* Physical and Chemical Research Institute 理化学研究所

** Ajinomoto Co., Ltd. 味の素株式会社

*** Zenno Agricultural Technical Center 全農農業技術センタ一

**** Nara Agricultural Experiment Station 奈良県農業試験場

***** Horticultural Research Station 農林省野菜試験場

1) Huang, K. T. and Misato, T. (1970). Rev. plant protect. (Tokyo), Res. 3, 12-23. 2) Yamaguchi, I., Taguchi, R., Huang, K. T. and Misato, T. (1969). J. Antibiot. (Tokyo), Ser. A. XXII, 463-466. 3) Honma, Y., shida, T. and Misato, T. (1973). Ann. phytopach. Soc. Japan, 39, 90-98. 
They were applied to the rice plant seedlings of the 4-leaf stage at the rate of $50 \mathrm{ml}$ per pot with a sprayer. After the sprayed solution had dried, spores of rice blast (Pyricularia oryzae), which had been cultivated in sterilized chaff medium (chaff $3 \mathrm{~g}$, sucrose $0.2 \mathrm{~g}$, yeast extract $0.01 \mathrm{~g}$, soluble starch $0.05 \mathrm{~g}$ ), were suspended in water and sprayed on the rice plant seedlings uniformly. The treated seedlings were then placed in an inoculation box of $27 \mathrm{C}$ and relative humidity of above $95 \%$ to be infected with the foregoing fungus. Four days after inoculation, the number of disease lesions per leaf was counted, and the preventive value was calculated according to the following equation.

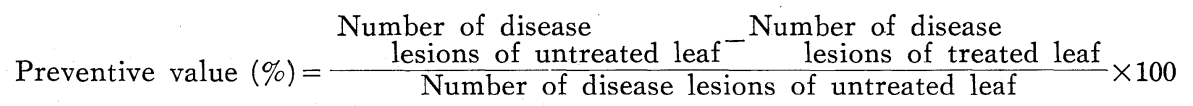

As the result it was found that the food additives shown in Table 1 showed preventive effects against rice blast disease.

Table 1. Protective Effects of Food Additives against Rice Blast

\begin{tabular}{l|r|c}
\hline \hline & $\begin{array}{c}\text { Average number of } \\
\text { disease lesions } \\
\text { per leaf }\end{array}$ & $\begin{array}{c}\text { Preventive value } \\
(\%)\end{array}$ \\
\hline Lecithin & 8.9 & 74 \\
Ferrous lactate & 13.9 & 62 \\
Tartaric acid & 8.2 & 76 \\
Nicotinamide & 17.1 & 50 \\
Alginic acid & 17.8 & 48 \\
Fumaric acid & 16.4 & 52 \\
Sorbic acid & 7.5 & 78 \\
5'-Ribonucleotide & 18.5 & 46 \\
Sodium polyphosphate & 8.2 & 76 \\
Sugar ester & 14.4 & 58 \\
Control & 34.2 & 0 \\
\hline
\end{tabular}

\section{Protective effects against vegetable diseases}

The tomato or cucumber seedlings were sprayed with food additives at a concentration of 2,000 $\mathrm{ppm}$. One day after spraying, the seedlings were inoculated and then placed in an inoculation box of $23 \mathrm{C}$. Evaluation was made at definite days after inoculation. As shown in Table 2, it was found that lecithin, sorbic acid and DL-tartaric acid were effective against late blight of tomatoes (Phytophthora infestans), anthracnose of cucumbers (Colletotrichum lagenarium) or gray mold of cucumbers (Botrysis cinerea).

\section{Effect of soybean lecithin in field tests}

Among the food additives shown in Table 2, soybean-lecithin was selected as the field test compound, since it can be readily available in great quantitis and low cost. From the results of field tests examined at the seven Agricultural Experimental Station in 1973, it was recognized that soybean lecithin at a concentration of $2,000 \mathrm{ppm}$ exhibited excellent preventive effects against some vegetable diseases such as strawberry powdery mildew (Sphaerotheca humuli) or cucumber powdery mildew (S. fuliginea), and cucumber anthracnose etc.. 
Table 2. Protective Effects of Food Additives against Vegetable Diseases

\begin{tabular}{|c|c|c|c|c|c|c|}
\hline Disease & \multirow{2}{*}{\multicolumn{2}{|c|}{$\begin{array}{l}\text { Late blight of tomatoes } \\
\text { "Fukuju", two seedlings }\end{array}$}} & \multicolumn{2}{|c|}{ Anthracnose of cucumbers } & \multicolumn{2}{|c|}{ Gray mold of cucumbers } \\
\hline Variety tested & & & \multicolumn{4}{|c|}{ "Sagamihanjiro", four seedlings per pot } \\
\hline Eood & $\begin{array}{l}\text { Per-cent of } \\
\text { disease area } \\
\text { per leaf }\end{array}$ & $\begin{array}{l}\text { Protective } \\
\text { value } \\
(\%)\end{array}$ & $\begin{array}{l}\text { Per-cent of } \\
\text { disease area } \\
\text { per leaf }\end{array}$ & $\begin{array}{c}\text { Protective } \\
\text { value } \\
(\%)\end{array}$ & $\begin{array}{c}\text { Length }(\mathrm{cm}) \text { of } \\
\text { disease lesions } \\
\text { per leaf }\end{array}$ & $\begin{array}{c}\text { Protective } \\
\text { value } \\
(\%)\end{array}$ \\
\hline Lecithin & 0 & 100 & 13 & 81 & 1.4 & 14 \\
\hline Ferrous lactate & 29.4 & 47 & 52 & 24 & 1.5 & 8 \\
\hline Fumaric acid & 19.4 & 65 & 76 & 0 & 1.4 & 14 \\
\hline Sorbic acid & 12.8 & 77 & 63 & 7 & 0.6 & 62 \\
\hline $5^{\prime}-\mathrm{GMP}$ & 29.2 & 51 & 65 & 4 & 1.6 & 0 \\
\hline $5^{\prime}$-UMP & 68.9 & 0 & 48 & 29 & 2.0 & 0 \\
\hline DL-Tartaric acid & 3.9 & 93 & 98 & 0 & 0.3 & 81 \\
\hline Nicotinamide & 27.2 & 51 & 43 & 37 & 0.8 & 48 \\
\hline Untreated & 55.6 & 0 & 68 & 0 & 1.6 & 0 \\
\hline Inoculation & \multicolumn{2}{|c|}{ spore suspension } & \multicolumn{2}{|c|}{ spore suspension } & \multicolumn{2}{|c|}{ mycelium } \\
\hline Observation & \multicolumn{2}{|c|}{$\begin{array}{l}\text { Four days after } \\
\text { inoculation }\end{array}$} & \multicolumn{2}{|c|}{$\begin{array}{l}\text { Five days after } \\
\text { inoculation }\end{array}$} & \multicolumn{2}{|c|}{$\begin{array}{l}\text { Three days after } \\
\text { inoculation }\end{array}$} \\
\hline
\end{tabular}

Table 3. Protective Effect of Soybean Lechitin against Cucumber Powdery Mildew

\begin{tabular}{c|c|c|c|c|c}
\hline Chemical & $\begin{array}{c}\text { Concentration } \\
(\mathrm{ppm})\end{array}$ & $\begin{array}{c}\text { Number of } \\
\text { total leaves }\end{array}$ & $\begin{array}{c}\text { Number of } \\
\text { diseased leaves }\end{array}$ & $\begin{array}{c}\text { Percent of } \\
\text { diseased leaves }\end{array}$ & $\begin{array}{c}\text { Diseased } \\
\text { index }\end{array}$ \\
\hline Lecithin (40\% W.P.) & 2,000 & 1,464 & 253 & 34.1 & 18.9 \\
Daconil (75\% W.P.) & 1,250 & 1,374 & 260 & 30.3 & 19.1 \\
Morestan (25\% W.P.) & 83 & 1,434 & 150 & 10.6 & 10.5 \\
\hline Control & & 1,372 & 486 & 60.0 & 35.7 \\
\hline
\end{tabular}

Diseased index $=\frac{\sum \text { diseased leaves in various grades } \times \text { index }}{\text { total leaves } \times 6} \times 100$

Percent of diseased area in leaf $<10 \% \quad 10 \sim 30 \% \quad 30 \sim 50 \% \quad>50 \%$

index $\quad 1 \quad 20 \begin{array}{llll}6 & 2 & 4 & 6\end{array}$

An example of field test against cucumber powdery mildew is shown in Table 3. This test was carried out in a greenhouse constructed of net sheets on the side parts and vinyl resin sheets on the top part. Cucumber seedlings (a susceptible variety "Wakasugi 30") were planted on the 13th of June.

The chemicals were sprayed on the leaves of the seedlings with a shoulderborne sprayer on three occasions: June 20, 27 and July 4, ensuring that both sides of the leaves were thoroughly wetted on each occasion. The treated test plants were left to spontaneous infection. On the 10th of July, the state of infection was examined. As shown in Table 3, soybean lecithin showed promising results.

Lecithin is an essential constituent of all cells of the human body, and the pathway of catabolism of lecithin in the organism is well-known. The average diet provides a daily intake of several grams of lecithin (approximately 1-5 g). Administration of lecithin in daily doses varying from 22 to $83 \mathrm{~g}$ for $2-4$ months was not accompanied 
by any untoward reactions. Estimate of acceptable dialy intake for man by WHO and FAO is $0-50 \mathrm{mg} / \mathrm{kg}$ body weight (unconditional acceptance) and $50-100 \mathrm{mg} / \mathrm{kg}$ body weight (conditional acceptance) $)^{4}$. The soybean lecithin is widely used in the food industry emulsifier and stabilizer in bread, ice-cream, chocolate, margarine and confectionery, as well as being utilized in the medical field as anticholesterol preparations. Therefore, soybean lecithin is an ideal fungicide demonstrating no mammalian toxicity, no phytotoxicity and no risk of its becoming a cause of pollution.

(Received July 1, 1974)

4) Seventh Report of the Joint FAO/WHO Expert Committes on Food Additives (1964). 